\title{
Analisis Pengelolaan Penangkapan Ikan kembung Lelaki (Rastrelliger kanagurta) secara Berkelanjutan di Perairan Selat Lombok
}

\author{
[Analysis on Sustainable Catch Management of \\ Indian Mackerel (Rastrelliger kanagurta) in Lombok Strait] \\ Bunyamin, Wahono Hadi P, O.D Subhakti Hasan ${ }^{凶}$ \\ Sekolah Tinggi Perikanan, Jurusan Penyuluhan Perikanan \\ Jalan Cikaret Nomor 1 Bogor 16001, Jawa Barat \\ Diterima: 12 Oktober 2016; Disetujui: 2 Desember 2016
}

\begin{abstract}
Abstrak
Penelitian ini bertujuan untuk menganalisis beberapa parameter aspek biologi reproduksi ikan kembung, menentukan status keberlanjutan pengelolaan ikan kembung berdasarkan dimensi ekologi, ekonomi, sosial, teknologi, dan etika serta menentukan strategi pengelolaan ikan kembung.Waktu penelitan mulai dari bulan Januari sampai Maret 2016, dilakukan melalui metode pendekatan survey. Pengambilan sampel ikan dilakukan secara random sampling. sedangkan penentuan respoden nelayan dilakukan secara purposive sampling. Hasil penelitian menujukkan Pola pertumbuhan ikan kembung lelaki baik yang jantan maupun betina bersifat allometrik negatif. Nisbah kelamin menunjukkan kondisi seimbang dengan perbandingan 1:1.Tingkat kematangan gonadnya yang dominan ditemukan TKG 4 sebanyak 31,66\%, TKG III sebanyak $30 \%$, ini diduga bahwa ikan kembung pada bulan tersebut sedang dalam proes pemijahan. Status keberlanjutan pengelolaan ikan kembung hasil MDS- RAPFISH sebesar 52 dengan status cukup berkelanjutan pada skala sustainabilitas 0-100. Nilai indeks keberlanjutan menunjukkan bahwa apabila pegelolaan dan pemanfaatan tetap seperti saat ini maka kegiatan penangkapan ikan kembung akan tetap berkelanjutan.Strategi pengelolaan diantaranya mengatur pembuangan limbah atau sampah pencemaran, mengatur daerah penangkapan, membatasi upaya penangkapan, meningkatkan pendidikan dan pegetahuan nelayan terhadap kelestarian lingkungan, revitalisasi aturan pengelolaan berdasarkan kearifan lokal, dan meningkatkan peranan penyuluhan perikanan.
\end{abstract}

Kata Kunci: Pengelolaan, Ikan Kembung Lelaki, Berkelanjutan, Selat lombok.

\begin{abstract}
This reasearch was aimed to analysis several parameter of biologic aspest indian mackerel especeally on its reproduction, to determine, its sustainable management sattus base ecological dimension, economy, sosial, tecknology and etics, also to determine int management strategy. The research stater from January-March 2016. Trough survey methode samples were taken randomly, whyle, fishermen respnden determined using purposive sampling. Result showed that growth pattern of famale wer allometric negative, sex ratio were in balanced condition with ratio 1:1. Gonad maturity stage wich were dominant found on TKG IV as much as $31,66 \%$. TKG III $30 \%$. This wase due to the Rastrelliger kanagurt on that mont were still in spawning condution. Sustainable management status rastrelliger kanagurta from MDS-Rapfish showed as much as 52 level of sutainable enough. Compare sustainablity scale 0-100. This sustainable indeks showed that if Rastrelliger kanagurta were well managed aid utilized the catch of Rastrelliger kanagurta that can will still sustainable management strtegy that can be aplplied are to arrange waste dischard / pollution, to arrange catch area. Increase fishermen eduacation and knowledge on sustainable environment, revitalization local wisdom and inproved the role fisheries extention.
\end{abstract}

Keywords: Indian Mackerel, Lombok Strait, Management, Sustainability.

$\triangle$ Penulis korespondensi

Alamat surel: otiedylan@gmail.com 


\section{PENDAHULUAN}

Selat Lombok termasuk dalam WPP 713-24 merupakan selat diantara Pulau Bali dan Pulau Lombok dengan total panjangnya $60 \mathrm{~km}^{2}$, kedalaman lebih dari 1000 m. Posisi selat Lombok terletak di wilayah transisi Indonesia bagian barat dan timur merupakan posisi strategis bagi area wilayah oseanografi sebagai salah satu lokasi lintas utama troughflow Indonesia disebut Arlindo, dimana terjadi pertukaran air antara samudera hindia dan samudera pasifik. Percampuran massa air dari dua area samudera yang berbeda dapat dijadikan indikator kesuburan perairan .

Sumberdaya ikan merupakan salah satu sumberdaya hayati yang dapat memberikan kontribusi yang cukup besar terhadap kesejahteraan bangsa, meskipun sumberdaya ikan dapat diperbaharui (renewbale) namun perlu kehati-hatian dalam pemanfaatannya untuk menjamin keberlanjutan, baik dalam segi jumlah maupun dalam kemampuannya untuk regenerasi. Adanya asumsi masyarakat nelayan akan sifat perikanan tangkap yang open acces telah memberi peluang bahwa setiap orang berhak dan bebas memanfaatkan dan memiliki sumberdaya tersebut secara bersama-sama (common property resources) sehingga eksploitasi atau pemanfaatan akan terus berjalan jika, tanpa pengaturan atau pengedalian upaya penangkapan ikan. Kondisinya menjadi cukup berbahaya ketika upaya penangkapan dengan tak mengindahkan kaidah-kaidah keberlanjutan sumberdaya akhirnya kondisi kelestarian sumberdaya ikan menjadi sangat terancam, itu berarti keberlanjutan sumberdaya juga terancam (Zulbainarni, 2012).

Ikan banyar/ikan kembung lelaki (Rastrelliger kanagurta) juga merupakan salah satu ikan pelagis kecil yang sangat potensial di daerah pantai dan ditemukan hampir diseluruh perairan Indonesia. Pada areal perairan Selat Lombok, ikan kembung lelaki termasuk ikan pelagis yang banyak ditangkap oleh nelayan di Kabupaten Lombok Barat. Sumberdaya ikan pelagis kecil memiliki beberapa karakteristik antara lain membentuk gerombolan, variasi rekruitmen cukup tinggi yang agak erat kaitannya dengan kondisi lingkungan yang labil, selalu melakukan ruaya baik temporal maupun spasial dan aktivitas gerak yang cukup tinggi yang ditunjukkan oleh bentuk badan yang menyerupai torpedo. Jika selama ini pengelolaan sumberdaya ikan hanya dikonsentrasikan kepada upaya bagaimana pencapaian hasil tangkapan yang maksimum, maka pada pengelolaan perikanan sekarang mempertimbangkan keseimbangan pemanfaatan sumberdaya 
ikan baik secara ekonomi, ekologi dan lingkungan. Aspek-aspek ini dipandang mempresentasikan dan mengindikasikan status usaha perikanan disuatu wilayah apakah berlanjut atau tidak.

\section{BAHAN DAN METODE}

Jenis Penelitian menggunakan metode penelitian survey. Pemilihan Sampel nelayan sebagai responden dilakukan secara Purposive Sampling (Sugiono, 2010) jumlah nelayan yang dijadikan sampel yaitu 80 orang nelayan yang melakukan penagkapan ikan di perairan Selat Lombok. Sedangkan penetuan jumlah sampling dari populasi ikan kembung (Rastrelliger kanagurta) menggunakan sampling kuota. Jumlah ikan kembung yang ditentukan dalam pengambilan sampel yaitu sebanyak 3035 ekor dengan interval pengambilan dua kali seminggu selama dua bulan yaitu bulan Februari dan bulan Maret, metode pengambilan sampel ikan dengan random sampling untuk memberikan peluang yang sama pada pupulasi ikan untuk dipilih menjadi anggota sampling.

\section{Hubungan Panjang dan Berat Ikan Kembung}

Hubungan panjang dan berat ikan kembung dianalisis menggunakan rumus: $\mathrm{W}=\mathrm{a} \mathrm{L}^{\mathrm{b}}$, dimana $\mathrm{W}=$ berat ikan (gram), $\mathrm{L}=$ panjang ikan $(\mathrm{mm}), \mathrm{a}$ dan $\mathrm{b}$ adalah koefisien pertumbuhan berat. Untuk memudahkan perhitungan, nilai $a$ dan $b$ ditransformasi kedalam persamaan linier dengan cara melogaritmakan persamaan tersebut sehingga menjadi: $\log \mathrm{W}=\log$ $a+b \log$ L (Efendi, 2002).

\section{Nisbah kelamin}

Untuk mengetahui perbandingan kelamin ikan kembung (Rastrelliger kanagurta) jantan dan betina dilakukan uji Chi-Kuadrat (Sugiono, 2008), yaitu :

\section{Tingkat Kematangan Gonad (TKG)}

Pengamatan tingkat Kematagan ditentukan secara morfologi berdasarkan bentuk, warna, ukuran ukuran bobot gonad, serta perkembangan isi gonad dengan mengacu pada Suwarso (2010).

\section{Analisis Status Berkelanjutan Ikan Kembung di Perairan Selat Lombok}

Analisis keberlanjutan Sumberdaya Ikan Kembung di Perairan Selat Lombok dilakukan dengan metode pendekatan Multi Dimensional Scalling (MDS) dengan analisis RAPFISH. Menurut Fauzi dan Anna (2008), RAPFISH merupakan suatu alat analisis untuk mengetahui sustainability dari perikanan multidisipliner. RAPFISH didasarkan pada suatu teknik ordinasi/menempatkan sesuatu pada urutan atribut yang terukur, dengan menggunakan Multi-Dimension Scalling (MDS). Dimensi dalam analisis RAPFISH menyangkut berbagai aspek 
keberlanjutan dari ekologis, ekonomi, teknologi, sosial dan soal etika. Setiap dimensi memiliki atribut atau indikator yang terkait dengan sustainability. Analisis keberlanjutan dengan teknik RAPFISH ini dimulai dengan meninjau ulang, melakukan identifikasi, dan mendefinisikan atribut perikanan yang digunakan. Setelah itu dilakukan juga penilaian (Scoring) perikanan yang dianalisis. Penilaian (Scoring) itu didasarkan pada ketentuan yang sudah ditetapkan dalam teknik RAPFISH. Analisis keberlanjutan yang digunakan dalam penelitian ini mengacu Fauzi dan Anna (2005) yang membagi status keberlanjutan dalam empat kategori yaitu: 1. Tidak Berkelanjutan (0-25), 2. Kurang Berkelanjutan (>25-50). 3. Cukup berkelanjutan (>50-70), 4. berkelanjutan (>75-100).

\section{HASIL DAN PEMBAHASAN}

\section{Hubungan Panjang dan Berat Ikan Kembung Lelaki}

Hubungan panjang dan berat ikan kembung lelaki yang jantan sebanyak 259 ekor menunjukkan nilai $\mathrm{W}=$ $0,0701 \mathrm{~L}^{2,474}$, koefisien determinasi 95 $\%$. Sedangkan hubungan panjang dan berat ikan kembung lelaki berjenis kelamin betina dengan jumlah sampel sebanyak 226 menunjukkan nilai $\mathrm{W}=$ $0,0701 \mathrm{~L}^{2.4748}$ dengan nilai koefisien determinasi 95\%. Hasil Uji t pada ikan kembung jantan dan betina diketahui bahwa pola pertumbuhan ikan kembung adalah allometrik Negatif (nilai $\mathrm{b}<3$ ) dimana pertambahan panjang tubuh ikan lebih cepat dari pertambahan beratnya, artinya ikan terebut panjang dan kurus yang disajikan Gambar 1 dan 2.

Hal yang sama, juga di peroleh dari hasil penelitian dilakukan oleh Suruwaky \& Gumaisah (2013) tentang identifikasi pada suatu tingkat eksploitasi sumberdaya jenis ikan kembung lelaki (Rasterelliger kanagurta) di tinjau dari hubungan panjang berat dengan sampel ikan yang tertangkap di perairan sorong dengan jumlah 300 ekor yang diambil pada September, Oktober dan November 2012, menunjukkan suatu pertumbuhan allometrik negatif yang ditandai dengan suatu nilai koefisien pertumbuhan $(b<3)$. Yudasmara (2014), bahwa pertumbuhan dapat dipengaruhi faktor eksternal dan internal diantaranya adalah jumlah dan ukuran makanan yang tersedia, jumlah makan yang menggunakan makanan yang tersedia, suhu, oksigen terlarut, kualitas air, umur dan ukuran ikan. 


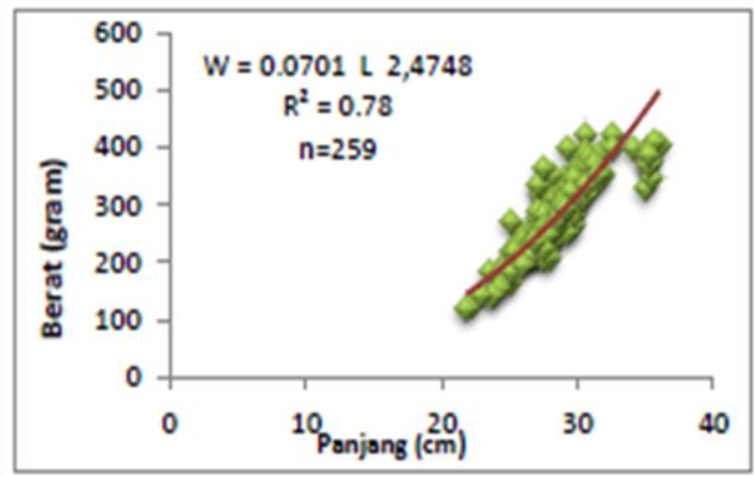

Gambar 1. Pertumbuhan Kembung Jantan

\section{Nisbah Kelamin}

Perbandingan ikan kembung jantan dan betina pada sejumlah sampel ikan kembung lelaki (Rastrelliger kanagurta) yang diamati sebanyak 485 ekor, yang terdiri atas: 259 ekor ikan jantan dan 226 ekor ikan betina dengan perbandingan jantan betina 1:1,14. Hasil perhitungan Chi-kuadrat 1:1, maka disimpulkan rasio kelamin jantan dan betina seimbang.

\section{Tingkat Kematangan Gonad/TKG}

Pengamatan Tingkat Kematangan Gonad/TKG terhadap 60 ekor ikan

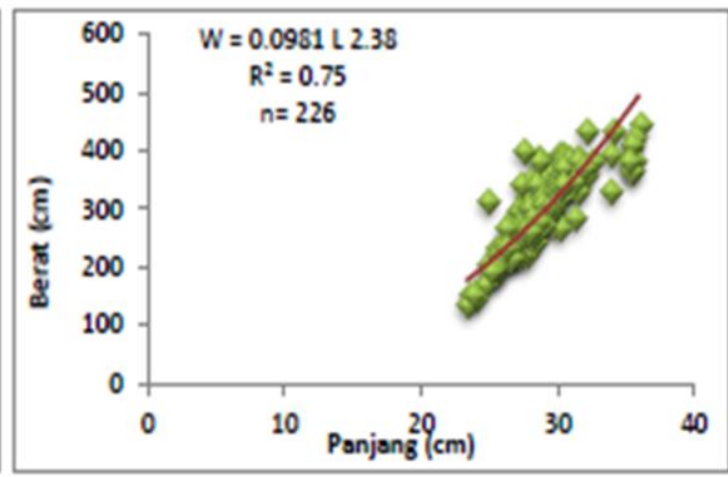

Gambar 2. Pertumbuhan Kembung Betina

kembung lelaki yang terdiri dari 32 ekor ikan jantan dan 28 ekor ikan betina, diperoleh gambaran sebagai berikut: TKG 1 di temukan sebanyak enam ekor atau $10 \%$, TKG 2 ditemukan sebanyak 17 ekor atau $28.33 \%$, TKG 3 ditemukan sebanyak 18 ekor atau $30 \% \mathrm{~cm}$. TKG 4 ditemukan sebanyak 19 ekor atau 31,66 $\%$. Persentase TKG 4 dan TKG III yang dominan diduga ikan tersebut dalam keadaan memijah sehingga perlu dibuat suatu pengaturan buka tutup area untuk kegiatan pada musim penangkapan.

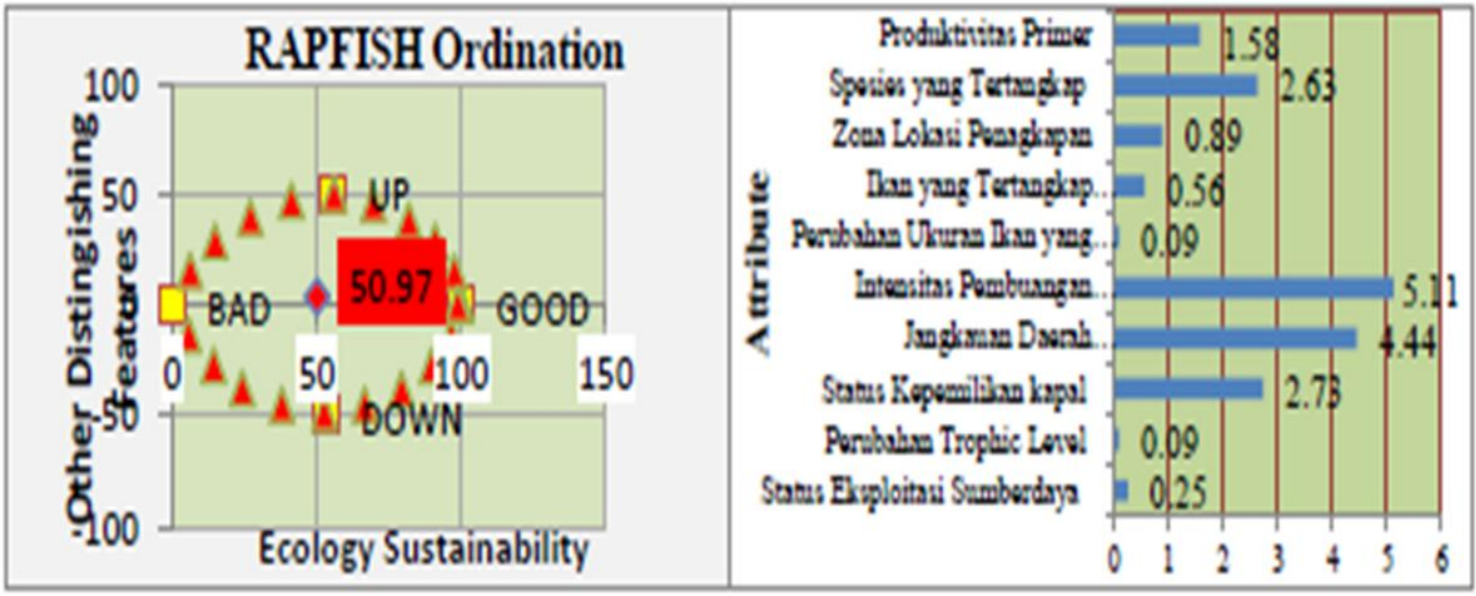

Gambar 3. Indeks Keberlanjutan ekologi dan Analisis Atribut Pengungkit

\section{Status Keberlanjutan Dimensi Ekologi}


Aanlisis Status Keberlanjutan Dimensi Ekologi dengan menggunakan RAPFISH terhadap seluruh atribut dimensi ekologi diperoleh nilai indeks keberlanjutan untuk sebesar 50,97 dengan status cukup berkelanjutan. Pada Gambar 3 terlihat menyajikan indeks keberlanjutan suatu dimensi ekologi dan analisis leverage.

Analisis leverage adalah untuk mengetahui suatu atribut yang sensitif memberikan pengaruh negatif terhadap status keberlanjutan ekologi. Atribut yang senstif pada dimensi ekologi yaitu intesitas kegiatan pembuangan sampah dan jangkauan daerah penangkapan.

\section{Status Keberlanjutan Dimensi Ekonomi}

Hasil analisis RAPFISH dimensi ekonomi memberikan suatu nilai indeks keberlanjutan sebesar 51,38 dengan status cukup berkelanjutan. Hasil Analisis Indeks keberlanjutan dimensi ekonomi dan analisis leverage disajikan pada Gambar 4.

Atribut yang berpengaruh posisitif didukung dengan berbagai komponen mempengaruhi status keberlanjutan pada dimensi ekonomi (Fauzi \& Ana, 2005). Walaupun kontribusi sektor perikanan terhadap PDRB masih tergolong rendah, Namun pendapatan Rata-rata nelayan berkisar antara Rp. 1.500.000,- Rp. 2.000.000.,/bulan, ini bahkan lebih tinggi dibandingkan dengan Upah Minimum Rata-rata/UMR Kabupaten Lombok Barat pada tahun 2015 yaitu sebesar Rp. 1.500.000,- Atribut-atribut yang cukup sensitif pada dimensi ekonomi yaitu hak kepemilikan sumberdaya dan juga pembatasan upaya penangkapan.
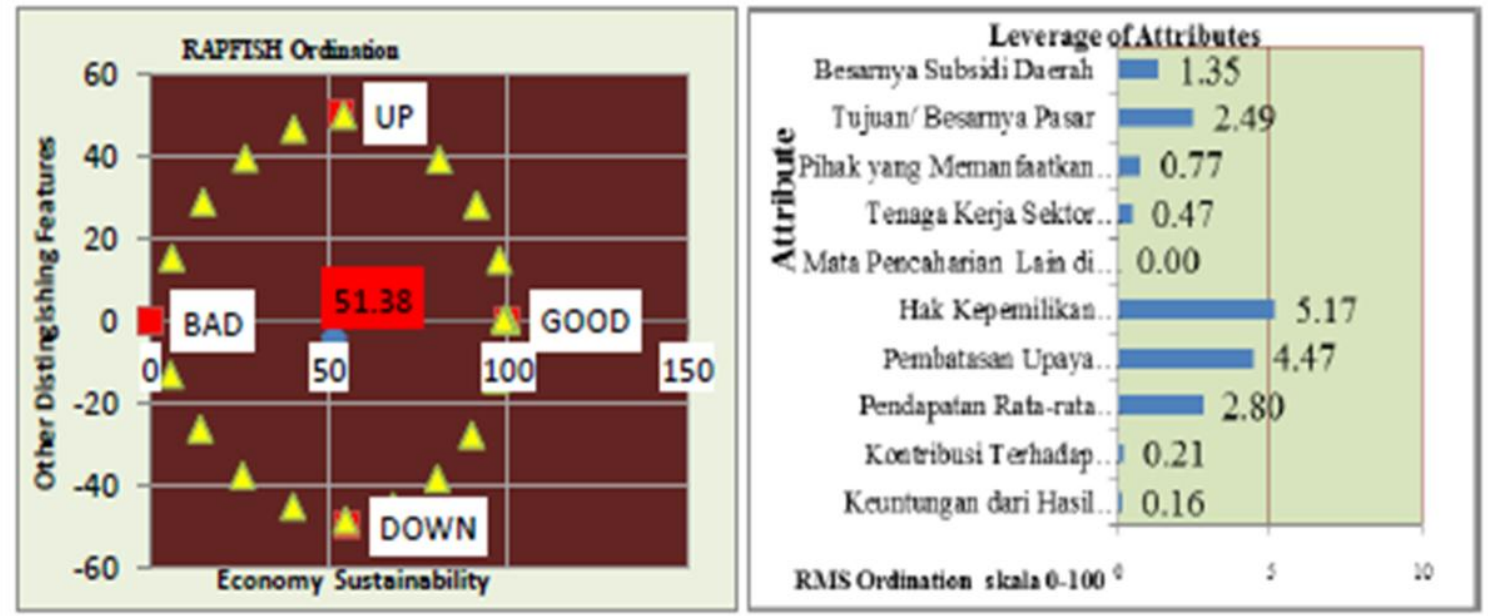

Gambar 4. Indeks dimensi ekonomi Analisis Pengungkit (Laverage) 


\section{Status Keberlanjutan Dimensi Sosial}

Analisis RAPFISH pada dimensi sosial menunjukkan indeks keberlanjutan sebesar 44,45, dengan status kurang berkelanjutan. Indeks keberlanjutan dimensi sosial dan analis leverage dimensi sosial disajikan pada Gambar 5.

Atribut sensitif dari dimensi sosial adalah tingkat pendidikan nelayan dan pegetahuan nelayan terhadap kelestarian lingkungan. Atribut tingkat pendidikan penduduk di suatu wilayah tertentu menggambarkan kondisi/tingkat kualitas sumberdaya manusia di wilayah tersebut, sehingga dampak dari aktivitasnya juga terkadang menjadi permasalahan dalam lingkaran yang cukup merumitkan dalam penyelesaiannya. Penyelesaian di tingkat pendidikan sebagian besar dari nelayan dicapai hingga Sekolah Dasar, sementara itu tercatat dari sejumlah responden nelayan sebanyak 80 orang, diperoleh data bahwa jumlah nelayan yang tidak tamat Sekolah Dasar sebanyak 34 orang nelayan atau sekitar $42,5 \%$, yang tamat Sekolah Dasar 33 orang nelayan atau $41,25 \%$ dan nelayan yang tamat Sekolah Menengah Pertama hanya 13 orang nelayan atau 16,25 \%. Menurut Budhiati (2011), dalam suatu kajiannya menyatakan bahwa jenjang tingkat pendidikan masyarakat dalam hal ini lebih dikaitkan dengan kemampuan dalam hal upaya menyerap dan atau menerapkan informasi di bidang pelestarian lingkungan serta kemampuan untuk berperan serta dalam gerakan pembangunan daerah yang berwawasan lingkungan. Masyarakat atau dalam hali ini responden nelayan yang memiliki pendidikan yang lebih tinggi pada umumnya memiliki pengetahuan yang lebih luas sehingga dapat lebih mudah menyerap dan menerima informasi (Fauzi \& Ana, 2008).

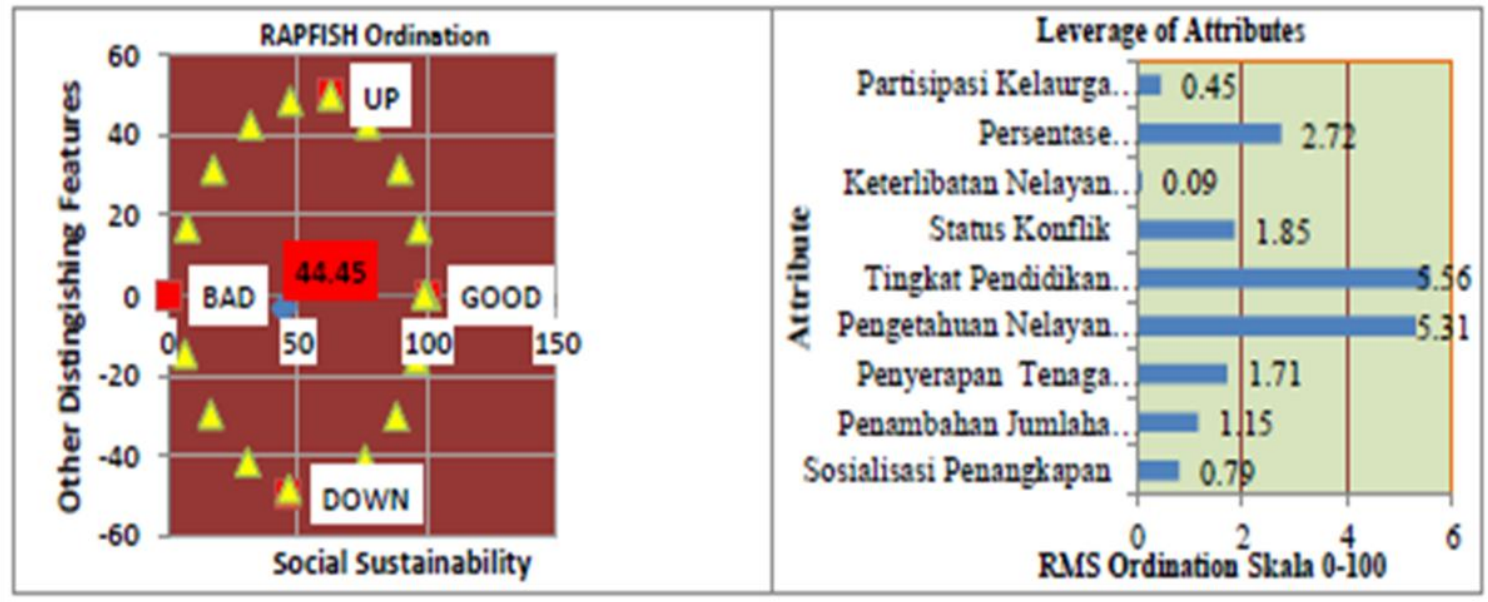

Gambar 5. Indeks dimensi Sosial Analisis Pengungkit (Laverage) 

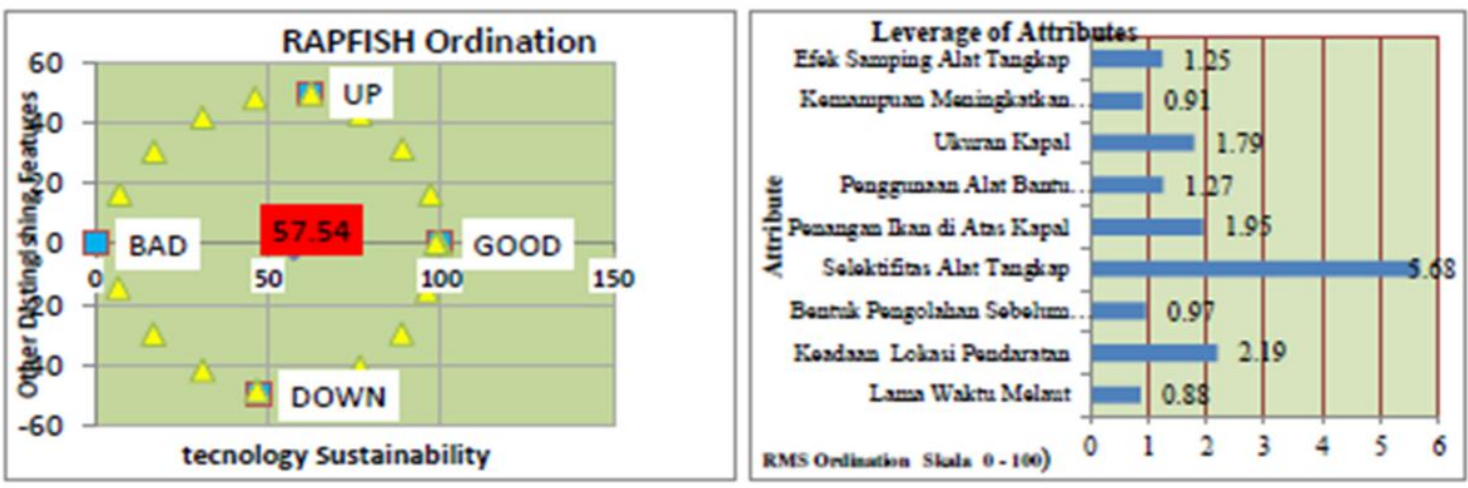

Gambar 6. Indeks dimensi Teknologi Analisis Pengungkit (Laverage)

\section{Status Keberlanjutan Dimensi}

\section{Teknologi}

Hasil olahan analisis RAPFISH menunjukkan pada Indeks keberlanjutan dimensi teknologi sebesar 57,54. dengan status cukup berkelanjutan. Indeks status keberlanjutan untuk dimensi Analisis Leverage CX dimensi teknlogi disajikan pada Gambar 6.

Kegiatan terkait perikanan tangkap umumnya dilakukan oleh para nelayan tradisional dengan armada penangkapan ikan berupa perahu motor tempel dan perahu tanpa motor dimana pemangkalan perahunya menyebar diseluruh pantai yang dekat dengan kawasan tempat tinggal mereka. Atiribut sensitif yang berpengaruh negatif adalah selektifitas alat tangkap dan keadaan lokasi pendaratan ikan alat tangkap yang digunakan untuk menangkap ikan kembung lelaki adalah jaring insang hanyut dimana alat tangkap ini merupakan alat tangkap yang ramah lingkungan namun, kurang selektif karena dapat menangkap ikan dari berbagai ukuran dan berbagai jenis ikan.

\section{Status Keberlanjutan Dimensi Etika}

Berdasarkan telaah hasil analisis RAPFISH menunjukkan bahwa nilai indeks keberlanjutan dimensi etika sebesar 57,63 dengan nilai status cukup berkelanjutan. Terkait nilai Indeks status keberlanjutan untuk dimensi etika dan Pengungkit disajikan pada Gambar 7.

Atribut sensitif dari hasil Analisis Leverage adalah aturan dari pengelolaan didasarkan pada tradisi atau hukum adat dan peranan para penyuluh perikanan. Tergerusnya nilai-nilai kearifan lokal salah satunya dikarenakan rendahnya kesadaran tentang nilai moral untuk menjaga lingkungan, ditambah lagi terhimpitnya kebutuhan hidup yang harus dipenuhi sehingga dalam upaya memanfaatkan sumberdaya ikan tidak mengindahkan kelestarian lingkungan. 

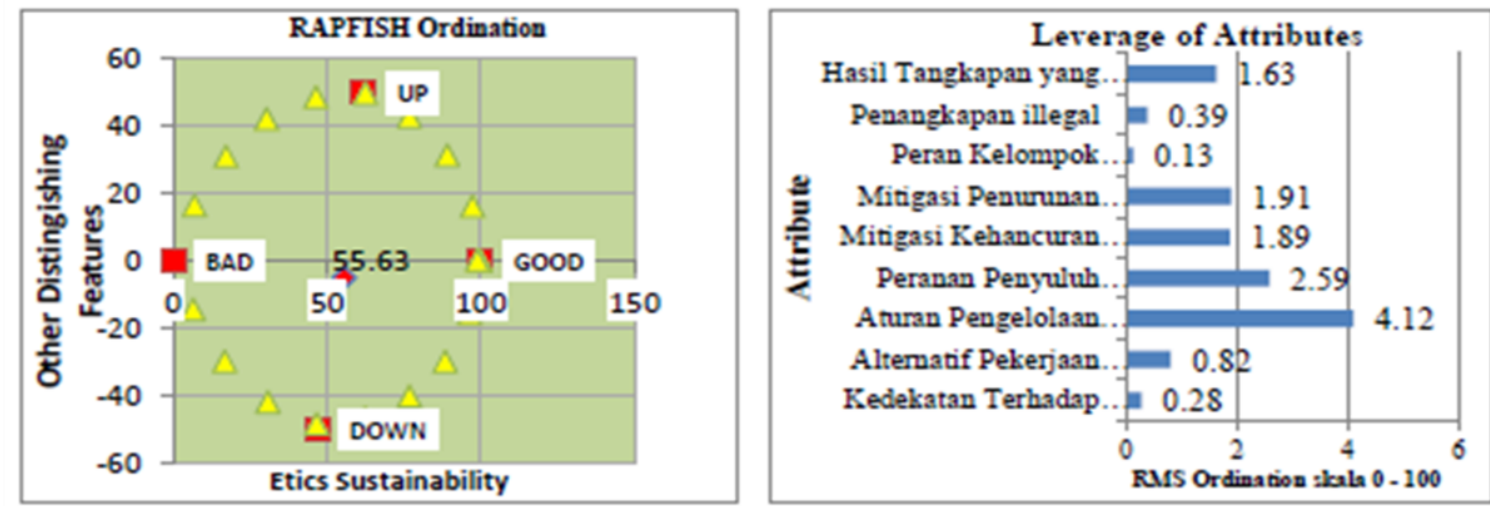

Gambar 7. Indeks dimensi Etika Analisis Pengungkit (Leverage)

Sementara itu keberadaan kegiatan penyuluhan perikanan di Kabupaten Lombok Barat sangat terbatas sehingga efektifitas peranan penyuluhan tidak berjalan dengan baik. Peranan penyuluhan perikanan dalam bidang penangkapan sangat diperlukan untuk mewujudkan suatu pemanfaatan dan pengelolaan pada sumberdaya perikanan tangkap yang berdaya saing, produktif dan menerapkan tata kelola berusaha yang berkelanjutan. Dari 12 orang penyuluhan perikanan PNS di Kabupaten Lombok Barat, hanya satu orang yang mempunyai keahlian di bidang penangkapan. Status pengelolaan multi dimensi dengan rata-rata nilai indeks keberlanjutan sebesar 52 dengan status cukup berkelanjutan disajikan dalam diamgran layang-layang pada Gambar 8.

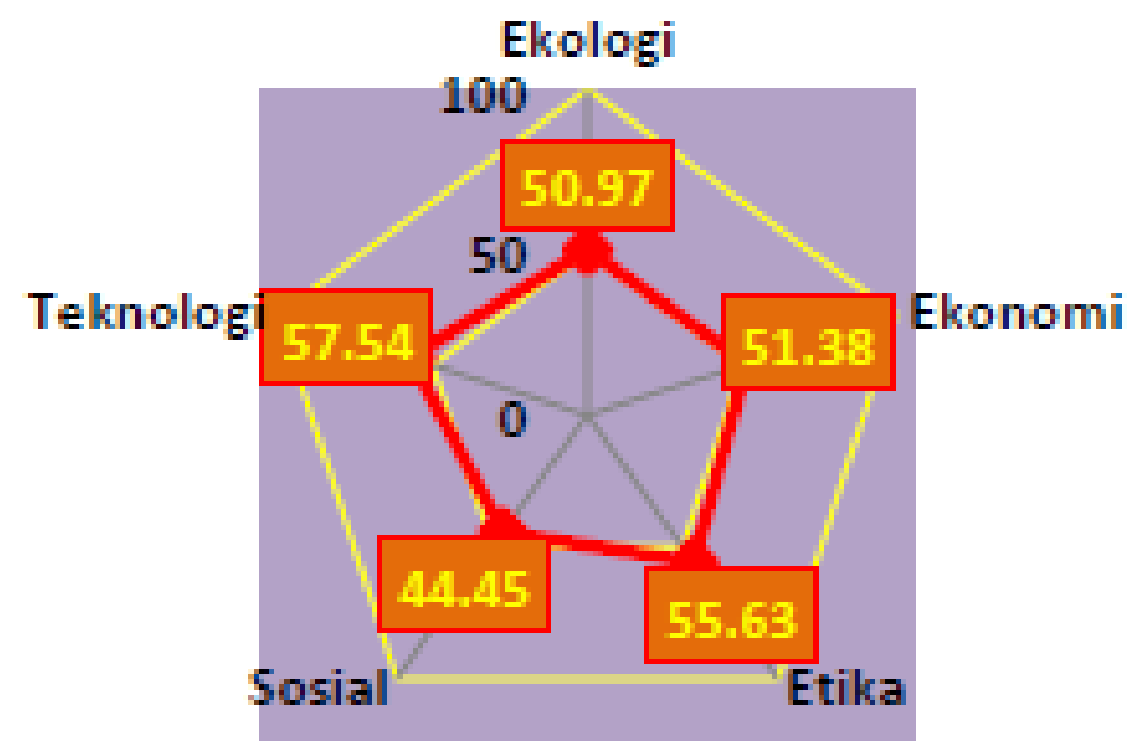

Gambar 8. Diagram Layang - layang status pengelolaan Ikan Kembung Lelaki 


\section{Strategi Pengelolaan}

Atribut sensitif pada tiap-tiap dimensi keberlanjutan dijadikan dasar penyusunan strategi pengelolaan ikan kembung yaitu Pengelolaan Pembuangan Sampah/Tingkat Pencemaran, Pembatasan upaya penangkapan dengan mengatur jumlah unit alat tangkap dan armada penangkapan, Meningkatkan Pendidikan dan Pengetahuan terhadap Kelestarian lingkungan; serta merevitalisasi Aturan Pengelolaan Berdasarkan Tradisi atau Awig-awig dan meningkatkan peranan penyuluhan perikanan.

\section{SIMPULAN}

1. Aspek Bilogi reproduksi ikan kembung berdasarkan hubungan panjang berat ikan kembung lelaki baik yang jantan maupun betina bersifat allometrik negatif yang berarti pertambahan panjang lebih cepat dari pertambahan berat, ini mengindikasikan adanya tekanan akibat peangkapan. Nisbah kelamin ikan jantan dan betina menunjukkan kondisi seimbang yaitu dengan perbandingan $1: 1$, perbandingan ini menunjukkan kondisi yang ideal dalam keberadaan suatu populasi. Porsentase TKG 4 dan TKG III diduga ikan tersebut dalam keadaan memijah sehingga perlu pengaturan buka tutup area atau musim penangkapan;

2. Status keberlanjutan ikan kembung dari hasil MDS-RAPFISH yaitu ratarata nilai indeks keberlanjutan sebesar 52 dengan kategori cukup yang berkelanjutan. Pada nilai indeks keberlanjutan ini juga menunjukkan bahwa apabila suatu pengelolaan dan pemanfaatan tetap seperti saat maka kegiatan penangkapan ikan kembung akan tetap berkelanjutan;

3. Strategi pengelolaan penangkapan ikan kembung lelaki yaitu mengatur pengelolaan dan pembuangan sampah atau limbah pencemaran, mengatur jarak dan daerah penangkapan untuk melindung stock ikan, membatasi upaya peangkapan, meningkatkan pendidikan nelayan dan pegetahuan terhadap kelestarian lingkungan, mengatur selektivitas alat tangkap melalui pengaturan mata jaring, revitalisasi pada aturan pengelolaan berdasarkan kearifan lokal atau awigawig, yang meningkatkan peranannya penyuluhan melalui suatu pembinaan, bimbingan, dan pendampingan.

\section{SARAN}

1. Penelitian ini dapat dijadikan bahan informasi dasar terkait kegiatan penyelenggaraan model penyuluhan perikanan mengenai pengolaan 
penangkapan ikan kembung secaara berkelanjutan di areal Perairan Selat Lombok.

2. Perlu dilakukan penelitian lebih lanjut mengenai hubungan dari beberapa parameter biologi antara pola pertumbuhan ikan kembung, nisbah kelamin, tingkat kematangan gonad, dan ukuran ikan kembung lelaki pertama kali matang gonad serta mengkaji aspek potensi dan upaya penangkapan yang dikaitkan dengan aspek reproduksi.

3. Sebagai suatu bahan masukan atau rekomendasi pada cara pengambilan keputusan dalam suatu pengelolaan sumberdaya ikan kembung yang baik, lestari dan juga berkelanjutan oleh Pemerintah Kabupaten Lombok Barat dan Pemerintah Provinsi NTB.

\section{DAFTAR PUSTAKA}

Budhiati. 2011. Hubungan antara kondisi sosial ekonomi, tingkat pendidikan dan pengetahuan tentang pengelolaan lingkungan dengan perilaku hidup sehat masyarakat di Kota Surakarta. Jurnal EKOSAINS IVol.III \Juli 2011.

Efendi M.I. 2002. Biologi perikanan. Yayasan pustaka nusantara. 105 hal.

Fauzy A, dan Anna S. 2005. Economic Valuation of Lembeh Strait Marine Protected (in Indonesia). Report to USAID and Government of Nort Sulawesi.
Fauzi A, dan Anna S. 2008. Pemodelan sumberdaya kelautan dan perikanan untuk analisis kebijakan PT. Gramedia Pustaka Utama. Jakarta 343. hal.

Sugiyono. 2010. Metode penelitian kuantitatif kualitatif dan $\mathrm{R}$ \& $\mathrm{D}$. Alfa Beta. Bandung $x+334$ hal.

Suruwaky AM, Gunaisah E, 2013. Identifikasi tingkat eksploitasi sumberdaya ikan kembung lelaki (Rastrelliger kanagurta) ditinjau dari hubungan panjang berat. Jurnal Akuatik Vol. IV (2) / September 2013.

Suwarso. 2010. Biologi reproduktif, preferensi habitat pemijahan dan dugaan stock pemijahan kembung Rastrelliger brachysoma, FAM. Scombridae di Pantura. Laporan Program Insentif Peningkatan Kemampuan Penenelti tahun 2010. Balai Riset Perikanan Laut, Badan Riset Kelautan dan Perikanan. Kementerian Kelautan dan Perikanan, Jakarta. 23 hal.

Yudasmara GA. 2014. Biologi perikanan. universitas pendidikan Ganesha press. Singaraja, 161 hal.

Zulbainarni N. (2012). Teori dan praktik pemodelan bioekonomi dalam pengelolaan perikanan tangkap. IPB Press. Kampus IPB taman Kencana Bogor 